\title{
Yoghurt Production Potential of Lactic Acid Bacteria Isolated from Leguminous Seeds and Effects of Encapsulated Lactic Acid Bacteria on Bacterial Viability and Physicochemical and Sensory Properties of Yoghurt
}

\author{
Eda E. Kılıç $\mathbb{D}^{1},{ }^{1}$ İbrahim Halil Kılıç $\mathbb{D}^{2}{ }^{2}$ and Banu Koç $\mathbb{B}^{3}$ \\ ${ }^{1}$ Naci Topçuoğlu Vocational School, University of Gaziantep, Gaziantep 27600, Turkey \\ ${ }^{2}$ Depatrment of Biology, Faculty of Art and Science, University of Gaziantep, Gaziantep 27310, Turkey \\ ${ }^{3}$ Fine Arts, Gastronomy and Culinary Arts, University of Gaziantep, Gaziantep 27310, Turkey
}

Correspondence should be addressed to Eda E. Kılıç; edakilic@gantep.edu.tr and İbrahim Halil Kılıç; kilic@gantep.edu.tr

Received 19 August 2021; Accepted 30 December 2021; Published 11 January 2022

Academic Editor: Saima Q. Memon

Copyright (c) 2022 Eda E. Kılıç et al. This is an open access article distributed under the Creative Commons Attribution License, which permits unrestricted use, distribution, and reproduction in any medium, provided the original work is properly cited.

\begin{abstract}
This study aims to determine the yoghurt production potential of lactic acid bacteria isolated from legumes seeds (lentils, beans, cowpea, and broad beans) and examine the effects of alginate capsules of selected starter cultures with high yoghurt production potential on the physicochemical properties, sensory properties of yoghurt, and bacterial viability during storage time at $4^{\circ} \mathrm{C}$. The exopolysaccharide (EPS), proteolytic activity, and acidification properties of eight different isolates were determined, and sixteen different yoghurt combinations prepared. The samples showed similar physicochemical $(\mathrm{pH}$, titratable acidity, dry matter, and whey separation), bacterial count, and sensory results in comparison with the commercial yoghurt used as a control sample. The acidity and $\mathrm{pH}$ of the yoghurt samples were significantly affected by the storage time. Total solids of yoghurt samples generally tend to decrease and syneresis of yoghurt samples also differed for each starter culture combination during the storage time. The total count of lactic acid bacteria during the storage time was higher than $10^{7} \mathrm{CFU} / \mathrm{g}$. The sensory analysis results of bacterial combinations are significantly different $(p<0.05)$. Results indicated that isolated starter cultures have potential as commercial starters to improve the quality of yoghurt. Selected starter cultures with yoghurt production potential were encapsulated. Lactic acid bacteria with encapsulation efficiency of $86,3 \pm 0,2$ and $82,26 \pm 0,79$ were selected for yoghurt production. The physicochemical properties of the yoghurt with free and encapsulated starter culture were significantly different during the storage time. The reduction $(\sim 0,5 \log \mathrm{cfu} / \mathrm{g})$ in the numbers of free and encapsulated starter cultures is over during the storage time $(p<0.05)$. The acceptability of yoghurt containing encapsulated bacteria was lower than the yoghurt containing free bacteria by the panelists. Consequently, it was determined that alginate capsules increased bacterial viability, but the sensory properties of yoghurt were affected adversely. The LAB isolated form legumes can be introduced to the national microbial collection.
\end{abstract}

\section{Introduction}

Lactic acid bacteria (LAB) are Gram-positive bacteria that is rod- or coccus-shaped that can produce lactic acid as the primary end product through heterofermentative or homofermentative metabolism. LAB are commonly found in traditional fermented foods such as yoghurt, cheese, sourdough, beverages, wine, sausages, olives, and others [1]. $\mathrm{LAB}$ are essential as starter culture for food fermentation due to enhancing food sensory properties and protective effect. It has been stated that the use of starter cultures assists in standardizing fermentation by controlling microbial flora $[2,3]$. L. bulgaricus and S. thermophilus are the dominant lactic acid bacteria in yoghurt production and are used as a starter culture [4]. Yoghurt is one of the most popular fermented dairy products around the world [5]. Yoghurt products are characterized by smooth texture, suitable viscosity, good flavour, and fermentation acidification. These properties have recently been considered as an important factor for yoghurt starter selection $[6,7]$. Both species are 
homofermentative, converting lactose into lactic acid [8] and producing volatile flavour compounds, such as diacetyl and acetaldehyde [9]. In yoghurt manufacturing, $\mathrm{pH}$ is decreased during the fermentation by starter culture, which converts lactose into lactic acid [10]. Proteolytic activity of starter culture formed amino acids, which contribute to the formation of flavour compounds. The starter culture generates typical flavour metabolites of yoghurt [11]. The physical properties of yoghurt gels play an important role in the quality and consumer acceptance [12]. Yoghurt texture mostly depends on strains of LAB and milk content. Exopolysaccharide- (EPS-) producer starter cultures are used in the fermentation of milk products because of their positive impact on the final product texture, stability, flavour, and aroma [13]. Yoghurt combines the nutritional and health benefits of milk ingredients with positive effects from yoghurt starter culture and numerous other active bacteria. These beneficial bacteria in yoghurt need to be active throughout their shelf life [14]. Milk, milk products, and yoghurt should contain $10^{7} \mathrm{CFU} / \mathrm{g}$ in a total of these microorganisms [15].

S. thermophilus and L. bulgaricus as starter cultures are essential for the production of standard, quality, and reliable yoghurt in the dairy industry. Starter culture production gains importance for the dairy industry to produce yoghurt with the desired quality and sensory properties. At the same time, starter culture production will be an important factor in the economy. The study on characterization of LAB is important for the development of new, industrial, and important cultures, but extremely few studies have been carried out to isolate and identify the LAB from the specific natural niches. Many natural products (broad bean, cowpea, lentil, bean, etc.) in Turkey have rich microflora that can provide yoghurt production. Legumes (such as beans, chickpea, lentils and peas, among other pulses belonging to the Fabaceae Family) are crops widely produced and consumed worldwide because of their nutritional quality. Developing indigenous cultures as a starter instead of imported cultures used in yoghurt production will be an important gain for the yoghurt industry. However, the inability to maintain bacterial viability, which is an important quality criterion in yoghurt production, poses an important problem for dairy technology. Preserving the stability and viability of bacteria in food during storage and transportation is important for standard production of yoghurt. At the dawn of this situation, encapsulation of starter culture provides protection to the bacteria and thus increases the viability of the delivered amount. For successful encapsulation of viable cells, it is important to preserve the bacterial viability under different handling processes along with the type of encapsulation material compatible with food material [16]. Microencapsulation is a widely known technology to increase bacterial viability and functionality. It is used for the preservation of probiotic viability during food processing in order to ensure the generally recommended dose of at least $10^{7} \mathrm{CFU} / \mathrm{g}$ or $\mathrm{mL}$ of food during the shelf life of the product [17]. Several methods (extrusion, emulsification, coacervation, spray drying, and freeze drying) have been developed for the encapsulation of bacteria for use in fermentation, as well as incorporating it into the product such as yoghurt, ice cream, spreads, and meat products. Alginate is one of the most widely used polymers for encapsulating the material due to cheapness, biocompatibility, and nontoxic matric [18]. There are numerous studies on yoghurt production, lactic acid bacteria, microencapsulation, and their properties. In our study, yoghurt production potentials and microencapsulation efficiency of lactic acid bacteria isolated and identified from legumes seeds have been determined. The aim of the present study is to investigate the yoghurt production potential of $\mathrm{LAB}$ isolated from leguminous seeds, which are natural products using EPS, proteolytic, and acidification activity, and determine the effects of microencapsulated starter cultures on the yoghurt properties regarding $\mathrm{pH}$, titratable acidity, dry matter, syneresis, bacterial count, and sensory characteristics.

\section{Materials and Methods}

2.1. Materials. Pasteurised cow milk (3\% fat) was purchased from the local market. LAB isolated from legumes, which were identified by 16sRNA sequence analysis, were used. $\mathrm{LAB}$ isolates were taken from culture stocks at the Biology Department at Gaziantep University and used and coded using the first letters of the legumes (lentil, bean, broad bean, cow pea) from S. thermophilus and L. bulgaricus (Table 1) [19]. Dr. Gusto brand milk powder is used for dry matter standardization. For microcapsules production, $\mathrm{Na}$-alginate (Alfasol) and CaCI2 (Merck) were used. For activating and enumerating the free and microcapsules $S$. thermophilus and L. bulgaricus, MRS and M17 culture medium (Merck Millipore, Germany) and agar-agar (Merck Millipore, Germany) were used. All glassware and solutions used in the analysis were sterilized at $121^{\circ} \mathrm{C}$ for $15 \mathrm{~min}$.

2.2. Yoghurt Production. A commercial pasteurized cow's milk was purchased, and the dry matter of milk was standardized to $16 \%$ with skimmed milk powder. The milk was heated to $95^{\circ} \mathrm{C}$ for $5 \mathrm{~min}$ and then cooled down to $42^{\circ} \mathrm{C}$. Starter cultures were added to the initial cell as the count of $10^{8} \mathrm{CFU} / \mathrm{g}$ by adjusting with the Mcfarland scale. S. thermophilus and L. bulgaricus were combined $(1: 1)$ and inoculated $(2 \% \mathrm{v} / \mathrm{v})$ into milk. Yoghurt samples were obtained in sixteen different combinations by 4 S. thermophilus and $4 L$. bulgaricus isolates (Table 2). Analyses were performed on the 1st, 7 th, and 14 th days of storage $\left(4^{\circ} \mathrm{C} \pm 1\right)$.

\subsection{Determination of Yoghurt Production Potentials of Isolated Bacteria}

2.3.1. Determination of EPS (Exopolysaccharide). Determination of EPS for LAB isolates was carried out regarding the study done by Valerie and Rawson [20]. EPS formation was quantified spectrophotometrically using the phenol sulphuric acid method [21]. Glucose was used for calibration, and the EPS amount is expressed as glucose equivalent $(\mathrm{mg} / \mathrm{mL})$. Tyrosine curve $\mathrm{R} 2$ value was found to be $0.9796(y=0,9015 x-0,1114)$. 
TABLE 1: Code of S. thermophilus and L. bulgaricus isolate and sources.

\begin{tabular}{lcc}
\hline Streptococcus. thermophilus isolates code & Lactobacillus bulgaricus isolates code & Source of isolates \\
\hline Lentil-coc (LC) & Lentil-bac (LB) & Lentil \\
Bean-coc (BC) & Bean-bac (BB) & Bean \\
Broad bean-coc (BBC) & Broad bean-bac (BBB) & Broad bean \\
Cow Pea-coc (CPC) & Cow Pea-bac (CPB) & Cow pea \\
\hline
\end{tabular}

Streptococcus thermophilus (C), Lactobacillus bulgaricus (B).

TABLE 2: Yoghurt combinations used in the study.

\begin{tabular}{lccccc}
\hline Sample & S. thermophilus & L. bulgaricus & Sample & S. thermophilus & L. bulgaricus \\
\hline 1 & LC & LB & 9 & CPC & CB \\
2 & LC & BB & 10 & CPC & BB \\
3 & LC & CPB & 11 & CPC & BBB \\
4 & LC & BBB & 12 & BBC & LB \\
5 & BC & LB & 13 & BBC & BB \\
6 & BC & BB & 14 & BBC & CPB \\
7 & BC & CPB & 15 & BBC & BBB \\
8 & BC & BBB & 16 & & \\
\hline
\end{tabular}

Lentil (L), Bean (B), Broad Bean (BB), Cow Pea (CP); S.thermophilus (C), L. bulgarıcus (B).

2.3.2. Proteolytic Activity. Hull [22] method was used to determine the proteolytic activities of the isolates. $1 \%$ from the activated cultures was inoculated into $10 \mathrm{~mL}$ skim milk, and samples were inoculated for $24 \mathrm{~h}$ at $28^{\circ} \mathrm{C} .5 \mathrm{~mL}$ of active culture was mixed with $1 \mathrm{~mL}$ distilled water and $10 \mathrm{~mL}$ $0.72 \mathrm{~N}$ Trichloroacetic acid (TCA) for 10 minutes. $5 \mathrm{~mL}$ of filtrate was placed in a $50 \mathrm{~mL}$ flask, and $10 \mathrm{~mL}$ of $\mathrm{Na}_{2} \mathrm{CO}_{3}$ $\mathrm{Na}_{4} \mathrm{P}_{2} \mathrm{O}_{7}$ solution was added and mixed. $3 \mathrm{~mL}$ of phenol reagent was added to the samples to obtain blue color. The samples were centrifuged at $5000 \mathrm{rpm}$ for 15 minutes (Hettich Zentrifugen, Mikro 22R, Deutschland). The absorbance (OD) of the supernatants was measured at $650 \mathrm{~nm}$ in a spectrophotometer (Shimadzu UV1700 UV-. VIS spectrophotometer, Japan). Results were expressed as milligrams of tyrosine released per $100 \mathrm{ml}$ of trichloroacetic acid filtrate.

2.3.3. Acidifying Capacity. Briefly, $10 \mathrm{ml}$ of reconstituted skim milk (RMS) was inoculated with $1 \%(\mathrm{v} / \mathrm{v})$ of each LAB preculture at $37^{\circ} \mathrm{C} . \Delta \mathrm{pH}$ values were measured with $\mathrm{pH}$-meter at the beginning of the incubation, at the 6th and 24th hours [23].

\subsection{Properties of Yoghurts}

2.4.1. Physicochemical Properties. The $\mathrm{pH}$ values of samples during storage were measured using a digital $\mathrm{pH}$-meter (ADWA AD 11). For titration acidity determination (TA), $10 \mathrm{~g}$ of yoghurt was diluted with distilled water then titrated with $0.1 \mathrm{~N} \mathrm{NaOH}$ using phenolphthalein as the indicator. TA was expressed as a percentage of lactic acid equivalents [4]. The dry matter contents of yoghurt samples were determined by the gravimetric method [24]. In the determination of syneresis, $5 \mathrm{ml}$ of yoghurt was centrifuged at $5000 \mathrm{rpm}$ for 20 minutes at $4^{\circ} \mathrm{C}$, and the separated whey was measured. Syneresis amount was expressed as the volume of separated whey per $100 \mathrm{ml}$ of yoghurt [25].
2.4.2. Bacterial Count. Yoghurt samples ( $1 \mathrm{~g})$ were weighed and diluted $9 \mathrm{ml}$ peptone water (Merck); then, serial dilutions were carried out. S. thermophilus and L. bulgaricus were counted, reported as the log cfu/g [26], and incubated at $37^{\circ} \mathrm{C}$ for $48 \mathrm{~h}$ and $72 \mathrm{~h}$, respectively, under anaerobic conditions [10].

2.4.3. Sensory Properties. The sensory properties of the yoghurt samples, such as the appearance, consistency using a spoon, consistency in the mouth, and smell and taste, were evaluated [27]. During the storage time (Table 3), a scale ranging from 1 (extremely poor) to 5 (very good) was used by eight trained panelists from the Department of Biology of Gaziantep University. Each sample was served in a white plastic cup, randomly coded with a 3-digit number.

\subsection{Microencapsulation Process}

2.5.1. Preparation of Cell Suspension. Selected starter cultures for microencapsulation were activated in MRS and $\mathrm{M} 17$ broth at $37^{\circ} \mathrm{C}$ for $48 \mathrm{~h}$ and $72 \mathrm{~h}$, respectively. Then, the cells were harvested by centrifuging (2000xg for $10 \mathrm{~min}$ ) and subsequently washed with a $0,85 \% \mathrm{NaCI}$ solution. The cells were then suspended in saline to obtain a solution containing approximately $10 \log \mathrm{CFU} \mathrm{g}^{-1}$. The cell suspension was used for microencapsulation.

2.5.2. Extrusion Technique. Beads were produced by modifying the methods reported by Bevilacqua et al. [18] and Turhan et al. [28]. Sodium-alginate was used as coating material at $2 \%$ and $3 \%$ concentrations. The cell suspension was mixed with $\% 2, \% 3 \mathrm{wt} / \mathrm{v}$ sodium alginate solution to obtain a desired core to wall ratio of $1: 2$ and $1: 4$ (Table 4) and homogenized using homogenizer (IKA-Ultra-Turrax) for $3 \mathrm{~min}$ at $3000 \mathrm{rpm}$. The mixture of sodium alginate and bacterial suspension was extruded to a $10 \mathrm{~mL}$ syringe and 
TABle 3: Properties of LAB.

\begin{tabular}{lccc}
\hline Isolates code & $\Delta \mathrm{pH}(24 \mathrm{~h})$ & EPS $(\mathrm{mg} / \mathrm{mL})$ & Proteolytic activity $(\mu \mathrm{g}$ tyrosine $/ \mathrm{mL})$ \\
\hline LC & $2,3^{\mathrm{a}}$ & $74^{\mathrm{a}}$ & $3,09^{\mathrm{a}}$ \\
BC & $2,3^{\mathrm{a}}$ & $150^{\mathrm{b}}$ & $2,19^{\mathrm{a}}$ \\
CPC & $2,3^{\mathrm{a}}$ & $266^{\mathrm{dc}}$ & $11,20^{\mathrm{a}}$ \\
BBC & $2,3^{\mathrm{a}}$ & $226^{\mathrm{c}}$ & - \\
LB & $2^{\mathrm{a}}$ & $299^{\mathrm{de}}$ & $62,59^{\mathrm{b}}$ \\
BB & $2,1^{\mathrm{a}}$ & $357^{\mathrm{e}}$ & $29,46^{\mathrm{ab}}$ \\
CPB & $2^{\mathrm{a}}$ & $312^{\mathrm{de}}$ & $22,25^{\mathrm{ab}}$ \\
BBB & $2,1^{\mathrm{a}}$ & $356^{\mathrm{e}}$ & $26,83^{\mathrm{ab}}$ \\
\hline
\end{tabular}

${ }^{*}$ Different letters within each column are statistically significant at $p<0.05$.

TABLE 4: Encapsulation efficiency (\%EE) of starter culture at different encapsulation conditions.

\begin{tabular}{|c|c|c|c|c|c|c|}
\hline Na-alginate\% (\%) & Core to wall & $\begin{array}{c}\text { LC } \\
\% \mathrm{EE}\end{array}$ & $\begin{array}{l}\mathrm{CPC} \\
\% \mathrm{EE}\end{array}$ & $\begin{array}{c}\mathrm{BC} \\
\% \mathrm{EE}\end{array}$ & $\begin{array}{c}\mathrm{BB} \\
\% \mathrm{EE}\end{array}$ & $\begin{array}{l}\text { BBB } \\
\% \mathrm{EE}\end{array}$ \\
\hline 2 & $\begin{array}{l}10: 20 \\
10: 40 \\
\end{array}$ & $\begin{array}{l}83,53 \pm 0,23^{\mathrm{aAB}} \\
82,41 \pm 0,18^{\mathrm{bBC}} \\
\end{array}$ & $\begin{array}{c}85,28 \pm 0,87^{\mathrm{aB}} \\
83,6 \pm 0,77^{\mathrm{aC}} \\
\end{array}$ & $\begin{array}{c}83,89 \pm 0,33^{\mathrm{aAB}} \\
81,39 \pm 0,53^{\mathrm{bB}} \\
\end{array}$ & $\begin{array}{c}81,93 \pm 1,58^{\mathrm{aAB}} \\
82,26 \pm 0,79^{\mathrm{aB}} \\
\end{array}$ & $\begin{array}{l}79,61 \pm 066^{\mathrm{aA}} \\
77,96 \pm 0,90^{\mathrm{aA}} \\
\end{array}$ \\
\hline 3 & $\begin{array}{l}10: 20 \\
10: 40\end{array}$ & $\begin{array}{c}83,68 \pm 0,87^{\mathrm{aCD}} \\
82,52 \pm 0,83^{\mathrm{aA}}\end{array}$ & $\begin{array}{c}86,3 \pm 0,2^{\mathrm{aD}} \\
85,56 \pm 1^{\mathrm{aB}}\end{array}$ & $\begin{array}{l}83,9 \pm 1,88^{\mathrm{aCD}} \\
81,24 \pm 2,62^{\mathrm{aA}}\end{array}$ & $\begin{array}{c}81,43 \pm 1,20^{\mathrm{aBC}} \\
80,06 \pm 0,23^{\mathrm{aA}}\end{array}$ & $\begin{array}{l}80,89 \pm 1,94^{\mathrm{aA}} \\
80,33 \pm 1,12^{\mathrm{aA}}\end{array}$ \\
\hline
\end{tabular}

Data were expressed as mean \pm standard deviation $(n=3)$. (a-b) Within a column, different superscript lowercase letters denote significant differences $(p<0.05)$ among the core to wall ratio in the same alginate concentration and bacteria. (A-D) Withina line, different supercript uppercase letters denote significant differences $(p<0.05)$ among the different starter culture in the same encapsulation conditions.

injected through a needle from a height of about $10 \mathrm{~cm}$ into a $0.05 \mathrm{~mol} / \mathrm{L} \mathrm{CaCl}_{2}$ solution in a magnetic stirrer at $400 \mathrm{rpm}$. The prepared beads were filtered and washed with sterile distilled water. An amount of moist microcapsules was frozen $\left(-20^{\circ} \mathrm{C}\right.$ for $\left.24 \mathrm{~h}\right)$ on the same day of production. Freeze drying was performed in lyophilizer with vacuum: $0.200-0.300 \mu \mathrm{Hg}$ and condenser temperature of $-52^{\circ} \mathrm{C}$.

2.5.3. Encapsulation Efficiency. The encapsulation efficiency (\%EE) was determined by using the following equation as described by Fareez et al. [29]:

$$
(\mathrm{EE})=\left(\frac{\log 10 \mathrm{~N}}{\log 10 \mathrm{No}_{\mathrm{o}}}\right) \times 100 .
$$

where $N$ is the number of viable cells $\left(\log C F U \cdot g^{-1}\right)$ released from the microcapsules, and $N_{0}$ is the number of viable cells $\left(\log \mathrm{CFU} \mathrm{g}^{-1}\right)$ in the cell concentrated prior to microencapsulation. Data were expressed as mean of three counts \pm standard error.

2.5.4. Bacterial Count. The dilution of the microcapsules consisted of weighing $1 \mathrm{~g}$ of wet microcapsules and $0.1 \mathrm{~g}$ of freeze-dried microcapsules, followed by the addition of $9 \mathrm{~mL}$ of phosphate buffer solution ( $\mathrm{pH}$ 7.5) [30]. The results were expressed as log CFU.mL-g.

2.6. Yoghurt Production with Encapsulated Starter Culture. A commercial pasteurized cow's milk was purchased, and the dry matter of milk was standardized to $16 \%$ using skimmed milk powder. After standardization, milk was heated to $95^{\circ} \mathrm{C}$ for $5 \mathrm{~min}$, cooled down to $42^{\circ} \mathrm{C}$, and inoculated with encapsulated starter culture. The acidification profile was recorded hourly monitored, and fermentation stopped by quickly refrigeration at $4^{\circ} \mathrm{C}$ for 14 days.

2.7. Statistical Analysis. SPSS Software (version 15.SPSS) was used for statistical analyses. The results were analyzed statistically using ANOVA analysis. Statistically significant differences among the means were determined by using Duncan's multiple range tests at $p<0.05$ level of significance.

\section{Results and Discussion}

3.1. Properties of Isolated Bacteria. The exopolysaccharide (EPS), proteolytic activity, and acidification properties of eight different isolates to adjust compatible isolates for producing yoghurt are shown in Table 3. LAB-producing EPS were chosen for their ability to improve the physical properties (regulating the structure, improving the viscosity and water holding capacity, and reducing whey separation) of dairy products [31]. In this study, EPS production for S. thermophilus and L. bulgaricus strains are $74-266 \mathrm{mg} / \mathrm{L}$ and 299-357 mg/L, respectively. The highest EPS production belongs to strain of $S$. thermophilus coded CPC $(266 \mathrm{mg} / \mathrm{mL})$. The highest EPS production belongs to the strain of L.bulgaricus coded BBB $(356 \mathrm{mg} / \mathrm{mL})$ and $\mathrm{BB}$ ( $357 \mathrm{mg} / \mathrm{mL}$ ). The range of $S$. thermophilus EPS is parallel to the study of Han et al. [32]. The range of L. bulgaricus EPS value is higher than the values for the studies Kilınç and Gezginç [33]. EPS values of different strains were statistically significant $(p<0.05)$. Proteolytic activity (PA) has an impact on the properties of the fermented product (Amani et al., 2016-34). PA differed from species to species, even among strains of the same species. The value proteolytic activity of L. bulgaricus isolates was higher than that of $S$. thermophilus 
isolates (Table 3), and this is compatible with the general properties of these species. L. bulgaricus has a more significant PA than S. thermophilus [34]. Among L. bulgaricus strains, the L. bulgaricus isolated from lentil coded LB has the highest PA $(60 \mu \mathrm{g}$ tyrosine $/ \mathrm{mL})$. The amount of PA of isolates coded as $\mathrm{CPB}, \mathrm{BB}$, and $\mathrm{BBB}$ is closer to the optimum value of $20 \mu \mathrm{g}$ [35]. It is observed that L. bulgaricus strains have stronger PA than $S$. thermophilus $(p<0.05)$. Acidification activity is one of the most important factors in starter culture selection in yoghurt production [36]. The acidification abilities of individual isolates were examined, and it was determined that their acid production ability is high $(\Delta \mathrm{pH}>2)$ for 8 isolates. After $24 \mathrm{~h}$ of incubation, the $\Delta \mathrm{pH}$ of the strains has similar values between 2,3 and 2,1 for strains S. thermophilus and L. bulgaricus (Table 3), respectively. The acidification activity values obtained in the present study are similar with the ones in the study of Altay Dede [37]. The $\Delta \mathrm{pH}$ values of $L$. bulgaricus isolates obtained from the legume seeds after 24 hours of incubation are lower than those obtained in previous studies [38]. The $\Delta \mathrm{pH}$ values of 6 strains of S.thermophilus obtained in a previous study [39] are similar with the ones obtained in this study. The strain difference is not statistically significant on acidification $(p>0.05)$. However, the acidification value obtained at the 1 st, 6th, and 24th days showed a statistically significant difference $(p<0.05)$.

3.2. Physicochemical Properties of Yoghurt. The physicochemical properties of yoghurt produced with S.thermophilus and L. bulgaricus isolated from the leguminous seeds and commercial yoghurt are presented in Table 5. The $\mathrm{pH}$ of the samples decreased until the 14th day of storage. The results showed that a decrease in $\mathrm{pH}$ value and an increase in titratable acidity (TA) were observed as a result of the continued activities of bacteria during the shelf life of yoghurt produced in the present study and commercial yoghurt. Similar results were reported in previous studies [14-41]. After 14 days of shelf life $\left(4^{\circ} \mathrm{C}\right)$, the $\mathrm{pH}$ of all yoghurts decreased and ranged from 4,51 to 4,25 . The effect of the combination of starter culture on the change of yoghurt $\mathrm{pH}$ is statistically significant $(p<0.05)$ (Table 5$)$. It states that the $\mathrm{pH}$ values obtained during storage are within the suitable limits for the rheological properties of yoghurt [42], and all combinations are considered to be suitable for industrial production due to $\mathrm{pH}$ value ( $\mathrm{pH}>4.0-4.1$ within 14 days) during storage [43]. For all yoghurt samples, it was observed that TA values increased during storage. This situation arises from the continuation of the acid-forming activities of the starter culture. On the 1st day of the storage, the effect of the combination of starter culture on the change of yoghurt TA is not statistically significant $(p>0.05)$ (Table 5$)$. The average TA of yoghurt samples on the 14th day of storage was determined as $0.78 \%$ of lactic acid. The results obtained in terms of change in TA during storage are in accordance with the results obtained from the studies conducted by Adhikari et al. [44], Karaca et al. [45], Xanthopoulos et al. [41], and Yllmaz [46]. The dry matter content of samples varied between $16.71 \%$ and $15,17 \%$ during the storage period. It is observed that the total dry matter of the yoghurt samples generally decreased slightly during storage (Table 5). Similar results were found in previous researches of Arslan and Bayrakçı [47]. El-Sayed et al. [48] stated that there was a decrease in dry matter during storage, while Pancar et al. [49] different results were observed, the total solids content of the samples was prepared with LBG, and the different gelation during storage remained almost constant. In the present study, the dry matter contents of the yoghurt samples were significantly $(p<0.05)$ affected by starter culture combinations. Syneresis is known as one of the most important quality properties in determining textural properties in the dairy industry. In Table 5, syneresis values of yoghurt samples during storage are different from each other. It was observed that syneresis decreased in eight combinations (CPC-BB, CPC-CPC, CPC-LB, BC-BB, $\mathrm{BC}-\mathrm{CPC}$, and $\mathrm{BC}-\mathrm{LB}$ ) of yoghurt samples and increased in the other eight combinations and commercial yoghurt. Karaca et al. [45] reported that the syneresis of yoghurt decreased, while Tarakçı and Küçüköner [5, 50] reported that the syneresis of yoghurt increased during storage. It is reported that different syneresis value is due to the acidity of yoghurt and the difference in starter culture used in yoghurt production [51]. The decrease in syneresis value is related to the water holding capacity attributed to the hydrophilic region of protein molecules that can be affected by $\mathrm{pH}$. The $\mathrm{pH}$ value lower than 4 increases the shrinkage within the clot and whey separation, since the water holding capacity of the proteins reaches the highest level for $\mathrm{pH} 4-4.6$, and lactic acid production must be ensured in order to be between these limits for the yoghurt $\mathrm{pH}[52,53]$. Although the $\mathrm{pH}$ values of all yoghurt samples are within the specified $\mathrm{pH}$ range, syneresis values are different. This is due to the use of different starter culture combinations. It was observed that the starter culture combination was statistically significant on the syneresis of yoghurt samples $(p<0.05)$ (Table 5). Combinations of yoghurt sample produced with S. thermophilus isolated from bean showed a lower syneresis value compared to the other yoghurt combinations. Syneresis values of yoghurt combinations containing BC, LC, and $\mathrm{CPC}$ eventually tended to decrease during storage. It has been determined in several studies that the amount of syneresis value of yoghurts decreased during storage [54].

3.3. Bacterial Count. Bacterial counts were enumerated, and results are shown in Table 5. For the different yoghurt combinations and commercial yoghurt on day 14 of storage, the total number of these microorganisms is higher than $10^{7} \mathrm{CFU} / \mathrm{g}$ (Table 5) in accordance with the recommendations of Codex Alimentarius [15]. The reduction in the number of starter culture $(\sim 0.5 \log \mathrm{cfu} / \mathrm{g})$ is similar and statistically significant during the storage period $(p<0.05)$. There are many studies reporting a decrease in the counts of yoghurt bacteria during storage [43-46] similar with the present study.

3.4. Sensory Properties. The most important feature that affects the consumer acceptance level is the sensory properties of the product. Sensory evaluations such as appearance 





TABLE 6: Sensory properties (flavour, odour, consistency, and appearance) of yoghurt samples.

\begin{tabular}{|c|c|c|c|c|}
\hline Starter combination & Appearance & Consistency & Odour & Flavour \\
\hline BBC-CPB & $3,56 \pm 0,19^{a}$ & $3,67 \pm 0,29^{\mathrm{ab}}$ & $4,5 \pm 0,33^{\mathrm{bcd}}$ & $3,94 \pm 0,19^{\text {bcdef }}$ \\
\hline BBC-LB & $4,33 \pm 0,29$ & $4,22 \pm 0,25^{\mathrm{cde}}$ & $4,31 \pm 0,05^{\mathrm{abc}}$ & $3,78 \pm 0,25^{\mathrm{bc}}$ \\
\hline $\mathrm{BBC}-\mathrm{BBB}$ & $4,44 \pm 0,25^{\mathrm{de}}$ & $4,39 \pm 0,10^{\mathrm{de}}$ & $4,22 \pm 0,25^{\mathrm{abc}}$ & $4,14 \pm 0,29^{\mathrm{def}}$ \\
\hline $\mathrm{BBC}-\mathrm{BB}$ & $4,44 \pm 0,10^{\mathrm{de}}$ & $4,06 \pm 0,25^{\text {abcd }}$ & $4,28 \pm 0,25^{\mathrm{a}}$ & $3,89 \pm 0,25^{\mathrm{def}}$ \\
\hline LC-CPB & $3,69 \pm 0,29^{\mathrm{ab}}$ & $3,61 \pm 0,25^{\mathrm{a}}$ & $4,06 \pm 0,17^{\mathrm{a}}$ & $3,81 \pm 0,05^{\mathrm{bcd}}$ \\
\hline LC-BBB & $3,83 \pm 0^{\mathrm{abc}}$ & $3,75 \pm 0,22^{\mathrm{abc}}$ & $3,92 \pm 0,22^{\mathrm{a}}$ & $3,39 \pm 0,19^{\mathrm{a}}$ \\
\hline LC-LB & $3,97 \pm 0,05^{\mathrm{abcd}}$ & $3,92 \pm 0,14^{\mathrm{abcd}}$ & $4,03 \pm 0,21^{\mathrm{a}}$ & $3,64 \pm 0,13^{\mathrm{ab}}$ \\
\hline LC-BB & $4,28 \pm 0,35^{\mathrm{cde}}$ & $3,97 \pm 0,29^{\text {abcd }}$ & $4,28 \pm 0,25^{\mathrm{abc}}$ & $3,83 \pm 0,17^{\text {bcde }}$ \\
\hline BC-CPB & $3,56 \pm 0,10^{\mathrm{a}}$ & $3,56 \pm 0,25^{\mathrm{a}}$ & $4,19 \pm 0,38^{\mathrm{abc}}$ & $3,83 \pm 0,33^{\text {bcde }}$ \\
\hline $\mathrm{BC}-\mathrm{BBB}$ & $4,22 \pm 0,42^{\mathrm{cd}}$ & $4,22 \pm 0,54^{\text {cde }}$ & $4,28 \pm 0,19^{a b c}$ & $4,22 \pm 0,19^{f}$ \\
\hline BC-LB & $4,06 \pm 0,35^{\mathrm{abcd}}$ & $4,22 \pm 0,35^{\mathrm{cde}}$ & $4,11 \pm 0,19^{\mathrm{ab}}$ & $3,89 \pm 0,10^{\text {bcde }}$ \\
\hline $\mathrm{BC}-\mathrm{BB}$ & $4,36 \pm 0,24^{\mathrm{de}}$ & $4,58 \pm 0,08^{\mathrm{ef}}$ & $4,25 \pm 0,17^{\mathrm{abc}}$ & $4,08 \pm 0,08^{\text {cdef }}$ \\
\hline СРC-СРB & $4,28 \pm 0,42^{\text {cde }}$ & $4,39 \pm 0,48^{\mathrm{de}}$ & $4,53 \pm 0,17^{\mathrm{cd}}$ & $4,06 \pm 0,10^{\text {cdef }}$ \\
\hline CPC-BBB & $4,28 \pm 0,42^{\mathrm{cde}}$ & $4,42 \pm 0,22^{\mathrm{de}}$ & $4,5 \pm 0^{\mathrm{bcd}}$ & $4,17 \pm 0,17^{\mathrm{ef}}$ \\
\hline CPC-LB & $4,11 \pm 0,10^{\mathrm{bcd}}$ & $4,14 \pm 0,21^{\text {bcde }}$ & $4,69 \pm 0,05^{\mathrm{de}}$ & $4,06 \pm 0,19^{\text {cdef }}$ \\
\hline CPC-BB & $4,78 \pm 0,38^{\mathrm{e}}$ & $4,39 \pm 0,10^{\mathrm{de}}$ & $4,89 \pm 0,10^{\mathrm{e}}$ & $4,19 \pm 0,05^{\mathrm{f}}$ \\
\hline Yoghurt & $4,78 \pm 0,1^{\mathrm{e}}$ & $5 \pm 0,00^{f}$ & $4,94 \pm 0,10^{\mathrm{e}}$ & $5 \pm 0,00^{\mathrm{g}}$ \\
\hline
\end{tabular}

Means with different lowercase letter in the same column indicate significant differences $(p<0.05)$.

and consistency (by spoon and mouth) of 16 different yoghurt samples are given in Table 5 . The highest mean score among yoghurt samples belongs to the sample containing $S$. thermophilus strain isolated from cowpea. The sensory properties of yoghurt, which coded as CPC-BB, have high total values. Consequently, it was determined that yoghurt combinations containing CPC strain provide the production of yoghurt with higher acceptability levels than other combinations. Statistical analysis results showed that the change in yoghurt combination was statistically significant on sensory results $p<0.05$ (Table 6).

3.5. Encapsulasion Efficiency. Table 4 shows the effects of alginate concentration and ratio of bacteria and encapsulating materials on encapsulation efficiency (EE) of beads. The EE of the capsules ranged between $\% 77,96$ and $\% 86,3$ after extrusion. The results are in line with the findings of Carbo et al. [55] and higher than Amine et el. [56] and Frakolaki et al. [57]. The highest EE was obtained at 3\% Na alginate concentration and core to wall ratio $1: 2$ ratio. In general encapsulation efficiency results encapsulated $1: 2$ exhibited higher EE than $1: 4$ core to wall ratio (Table 4 ). Similar results were obtained in the study of Rajam and Annadharamakrishnan [58]. Encapsulation efficiency is different for each strain under the same encapsulation conditions $(p<0.05)$.

3.6. Properties of Yoghurt Produced by Microencapsulated Dtarter Culture. After the extrusion, wet microcapsules were freeze-dried in a lyophilizer (Labconko) to obtain power microcapsules. In both treatments (extrusion and freeze drying), count encapsulated bacteria, in accordance with the recommendations from the Codex Alimentarius [15] (Table 7). Freeze-drying has been used to produce probiotic powder for decades, but the combination of freeze drying and encapsulation is a relatively new concept [59]. The viability bacteria after extrusion and freeze drying ranged from $9.16 \mathrm{cfu} / \mathrm{g}$ to $8.44 \mathrm{cfu} / \mathrm{g}$ and $8.72 \mathrm{cfu} / \mathrm{g}$ and $6.84 \mathrm{cfu} / \mathrm{g}$, respectively.

Yoghurt was produced with a starter culture (CPC$\mathrm{BB}$ ) combination with high EE (Table 4) used to investigate the effect of encapsulation on the physicochemical, microbiological, and sensory properties of yoghurt (Table 8). The $\mathrm{pH}$ change of yoghurts with free and encapsulated bacteria was from 4.7 and 4.81 to 4.42 and 4.93, respectively. During the storage time, the $\mathrm{pH}$ in the yoghurt with encapsulated bacteria is higher than that of free bacteria. Similar results are demonstrated by Kailasapathy [60]. This can be attributed to the effect on $\mathrm{pH}$ of sodium alginate $(\mathrm{pH} 7.25)$ used as capsule material. Syneresis values during storage are lower in yoghurts containing capsules. This may be due to the hygroscopic property of alginate. The higher dry matter ratio of yoghurt containing encapsulated bacteria compared to dry matter of yoghurt containing free bacteria The reductions in the numbers of free and encapsulated bacteria were similar and statistically significant $(p<0.05)$. Similar results were demonstrated by Sultana et al. [61].

Yoghurts with encapsulated bacteria had lower score for each sensorial characteristics than the yoghurts with free starter cultures (Table 9) $(p<0.05)$. These results are due to the fact that the capsules can be seen clearly without melting in the structure and are perceived sensory. The appearance/ taste of yoghurts with encapsulated bacteria was considered a defect in the encapsulated type of yoghurts by the panelists. Similar results were reported by Kailasapathy [60], who observed a significant change in the textural properties, particularly smoothness, of yoghurts containing encapsulated bacteria. Adhikari et al. [62] also determined that the sensory properties of yoghurts with free probiotic bacteria were better than those of yoghurts with encapsulated bacteria. 
TABLE 7: Viability of encapsulated starter culture $\left(\mathrm{cfu}^{\mathrm{gr}} \mathrm{gr}^{-1}\right)$ after extrusion and freeze drying.

\begin{tabular}{|c|c|c|c|c|c|c|c|}
\hline & Alginate (\%) & Core to wall & $\mathrm{LC}$ & CPC & $\mathrm{BC}$ & $\mathrm{BB}$ & $\mathrm{BBB}$ \\
\hline After extrusion & 2 & $\begin{array}{l}10: 20 \\
10: 40 \\
10: 20 \\
10: 40\end{array}$ & $\begin{array}{c}8,89 \pm 0,02^{\mathrm{aA}} \\
8,77 \pm 0,02^{\mathrm{bB}} \\
8,9 \pm 0,1^{\mathrm{aAB}} \\
8,78 \pm 0,09^{\mathrm{aA}}\end{array}$ & $\begin{array}{c}9,05 \pm 0,87^{\mathrm{bA}} \\
8,87 \pm 0,77^{\mathrm{bB}} \\
9,16 \pm 0,22^{\mathrm{aB}} \\
9,08 \pm 1^{\mathrm{aB}}\end{array}$ & $\begin{array}{l}8,82 \pm 0,03^{\mathrm{aA}} \\
8,56 \pm 0,06^{\mathrm{bA}} \\
8,82 \pm 0,20^{\mathrm{bA}} \\
8,54 \pm 0,27^{\mathrm{bA}}\end{array}$ & $\begin{array}{c}8,8 \pm 0,17^{\mathrm{aA}} \\
8,84 \pm 0,08^{\mathrm{aB}} \\
8,88 \pm 0,13^{\mathrm{bAB}} \\
8,73 \pm 0,02^{\mathrm{bA}}\end{array}$ & $\begin{array}{c}8,62 \pm 0,51^{\mathrm{aA}} \\
8,44 \pm 0,1^{\mathrm{aA}} \\
8,76 \pm 0,21^{\mathrm{bA}} \\
8,7 \pm 0,12^{\mathrm{bA}}\end{array}$ \\
\hline After freeze drying & 3 & $\begin{array}{l}10: 20 \\
10: 40 \\
10: 20 \\
10: 40\end{array}$ & $\begin{array}{c}8,26 \pm 0,14^{\mathrm{aAB}} \\
7,89 \pm 0,1^{\mathrm{bA}} \\
8,14 \pm 0,1^{\mathrm{aA}} \\
8,01 \pm 0,15^{\mathrm{aA}}\end{array}$ & $\begin{array}{l}8,72 \pm 0,11^{\mathrm{aB}} \\
8,36 \pm 0,03^{\mathrm{bB}} \\
8,61 \pm 0,06^{\mathrm{aB}} \\
8,69 \pm 0,24^{\mathrm{aB}}\end{array}$ & $\begin{array}{c}8,35 \pm 0,1^{\mathrm{aB}} \\
8,32 \pm 0,23^{\mathrm{aB}} \\
8,46 \pm 0,16^{\mathrm{bB}} \\
8,48 \pm 0,21^{\mathrm{bB}}\end{array}$ & $\begin{array}{c}8,13 \pm 0,04^{\mathrm{aAB}} \\
7,97 \pm 0,08^{\mathrm{bA}} \\
8,16 \pm 0,17^{\mathrm{aA}} \\
8,06 \pm 0,17^{\mathrm{aA}}\end{array}$ & $\begin{array}{l}8,08 \pm 0,20^{\mathrm{aA}} \\
7,87 \pm 0,03^{\mathrm{aA}} \\
7,94 \pm 0,09^{\mathrm{bA}} \\
7,84 \pm 0,12^{\mathrm{bA}}\end{array}$ \\
\hline
\end{tabular}

Mean results of three independent trials \pm standard deviation. Means values within a line (at the same encapsulation condition) for each strain indicate significant differences $(p<0.05)$. Means value within a column indicate differences between core and wall at the same alginate concentration $(\% 2 ; \% 3)$ for each starin.

TABLE 8: pH, titration acidity, syneresis, count bacteria, and dry matter value of yoghurt including encapsulated and free bacteria.

\begin{tabular}{lccc}
\hline & Storage day & Free bacteria (BBC-BB) & Encapsulated bacteria (BBC-BB) \\
\hline \multirow{2}{*}{ pH } & 1 & $4,7 \pm 0,0^{\mathrm{a}}$ & $4,81 \pm 0,01^{\mathrm{b}}$ \\
& 7 & $4,53 \pm 0,01^{\mathrm{a}}$ & $4,87 \pm 0,03^{\mathrm{b}}$ \\
\hline \multirow{3}{*}{ Syneresis } & 14 & $4,42 \pm 0.05^{\mathrm{a}}$ & $4,93 \pm 0,02^{\mathrm{b}}$ \\
\hline \multirow{3}{*}{ Dry matter } & 1 & $63,82 \pm 2,03^{\mathrm{a}}$ & $39,57 \pm 3,12^{\mathrm{b}}$ \\
& 7 & $63,34 \pm 0,34^{\mathrm{a}}$ & $47,46 \pm 5,27^{\mathrm{b}}$ \\
& 14 & $59,46 \pm 0,16^{\mathrm{a}}$ & $42,64 \pm 3,51^{\mathrm{b}}$ \\
\hline \multirow{3}{*}{ Count bacteria } & 1 & $16,09 \pm 0,01^{\mathrm{a}}$ & $17,82 \pm 0,71^{\mathrm{b}}$ \\
& 7 & $15,95 \pm 0,11^{\mathrm{a}}$ & $17,99 \pm 0,59^{\mathrm{b}}$ \\
\hline \multirow{3}{*}{ Titratable acidity \%LA } & 14 & $16,33 \pm 0,11^{\mathrm{a}}$ & $17,81 \pm 0,19^{\mathrm{b}}$ \\
& 1 & $10,97 \pm 0,01^{\mathrm{a}}$ & $11,21 \pm 0,04^{\mathrm{b}}$ \\
& 7 & $10,88 \pm 0,0,02^{\mathrm{a}}$ & $11,04 \pm 0,15^{\mathrm{b}}$ \\
& 14 & $10,84 \pm 0,01^{\mathrm{a}}$ & $10,92 \pm 0,03^{\mathrm{b}}$ \\
\hline
\end{tabular}

(a, b) Different superscripts within the same line indicate significant differences $(p<0.05)$.

TABLE 9: Sensory evaluation scores (mean \pm SD) of yoghurts.

\begin{tabular}{lcccc}
\hline Treatment & Appearance & Consistency & Odour & Flavour \\
\hline Yoghurt + Free bacteria & $4,78 \pm 0,38^{\mathrm{a}}$ & $4,39 \pm 0,10^{\mathrm{a}}$ & $4,89 \pm 0,10^{\mathrm{a}}$ & $4,19+0,05^{\mathrm{a}}$ \\
Yoghurt + Encapsulated bacteria & $3,5 \pm 0,17^{\mathrm{b}}$ & $4,06 \pm 0,49^{\mathrm{b}}$ & $4,44 \pm 0,38^{\mathrm{b}}$ & $3,28 \pm 0,75^{\mathrm{b}}$ \\
\hline
\end{tabular}

(a, b) Mean values within a column with the different lower letters are significantly different from each teatment for sensory characteristic at $p<0.05$.

\section{Conclusion}

The results indicated that isolated starter cultures have potential as commercial starters to improve the quality of yoghurt. This study is a good example of the presence of the LAB strains in different environments including legumes. Developing indigenous cultures as a starter instead of imported cultures used in yoghurt production will be an important gain for the yoghurt industry. The differences in the physicochemical properties of yoghurts containing free and encapsulated bacteria were due to alginate capsules. Yoghurts with alginate capsules have higher $\mathrm{pH}$ and dry matter ratio than yoghurt with free bacteria However, the fact that the capsules that did not melt during the storage were felt during the tasting adversely affected the sensory results of the yoghurt. Further research is needed to determine capsules that will provide adequate protection during the storage without adversely affecting sensory characteristics of yoghurt.

\section{Data Availability}

The data used to support the findings of this study are included within the article.

\section{Conflicts of Interest}

The authors declare that there are no conflicts of interest regarding the publication of this paper.

\section{Acknowledgments}

The authors are grateful to the Gaziantep University Scientific Research Projects Department for financial support provided for this project (Project No: FEF 19.35). 


\section{References}

[1] M. L. Marco, D. Heeney, S. Binda et al., "Health benefits of fermented foods: microbiota and beyond," Current Opinion in Biotechnology, vol. 44, pp. 94-102, 2017.

[2] T. Xiong, X. Li, Q. Guan, F. Peng, and M. Xie, "Starter culture fermentation of Chinese sauerkraut: growth, acidification and metabolic analyses," Food Control, vol. 41, pp. 122-127, 2014.

[3] R. K. Robinson, "Fermented milks | yoghurt, role of starter cultures," in Encyclopedia of Dairy Science, H. Roginski, J. Fuquay, and P. Fox, Eds., Academic Press, England, UK, 2002.

[4] R. I. Dave and N. P. Shah, "Viability of yoghurt and probiotic bacteria in yoghurts made from commercial starter cultures," International Dairy Journal, vol. 7, no. 1, pp. 31-41, 1997.

[5] M. C. McKinley, "The nutrition and health benefits of yoghurt," International Journal of Dairy Technology, vol. 58, no. 1, pp. 1-12, 2005.

[6] B. De Ancos, M. Pilar Cano, and R. Gómez, "Characteristics of stirred low-fat yoghurt as affected by high pressure," International Dairy Journal, vol. 10, no. 1-2, pp. 105-111, 2000.

[7] O. N. Donkor, A. Henriksson, T. Vasiljevic, and N. P. Shah, "Effect of acidification on the activity of probiotics in yoghurt during cold storage," International Dairy Journal, vol. 16, no. 10, pp. 1181-1189, 2006.

[8] A. Tamime and V. Marshall, Microbiology and Technology of Fermented Milks. Mikrobiology and biochemiSy of Cheese and Fermented Milk, Springer, Berlin, Germany, 1997.

[9] H. Cheng, "Volatile flavor compounds in yogurt: a review," Critical Reviews in Food Science and Nutrition, vol. 50, no. 10, pp. 938-950, 2010.

[10] D. Sert, E. Mercan, and E. Dertli, "Characterization of lactic acid bacteria from yogurt-like product fermented with pine cone and determination of their role on physicochemical, textural and microbiological properties of product," Lebensmittel-Wissenschaft \& Technologie, vol. 78, pp. 70-76, 2017.

[11] M. Liu, A. Nauta, C. Francke, and R. J. Siezen, "Comparative genomics of enzymes in flavor-forming pathways from amino acids in lactic acid bacteria," Applied and Environmental Microbiology, vol. 74, no. 15, pp. 4590-4600, 2008.

[12] W.-J. Lee and J. A. Lucey, "Rheological properties, whey separation, and microstructure in set-style yogurt: effects of heating temperature and incubation temperature," Journal of Texture Studies, vol. 34, no. 5-6, pp. 515-536, 2003.

[13] P. Ruas-Madiedo, J. Hugenholtz, and P. Zoon, "An overview of the functionality of exopolysaccharides produced by lactic acid bacteria," International Dairy Journal, vol. 12, no. 2-3, pp. 163-171, 2002.

[14] K. Kycia, A. Chlebowska-Śmigielb, A. Szydłowskac, E. Sokółd, M. Ziarnod, and M. Gniewosz, "Pullulan as a potential enhancer of Lactobacillus and Bifidobacterium viability in synbiotic low fat yoghurt and its sensory quality," Food Science and Technology, vol. 128, pp. 109-414, 2020.

[15] Codex, Codex Standard for Fermented Milks (Codex Stan 2432003) Food and Agriculture Organization, United Nation, Roma, Italy, 2003.

[16] F. B Haffner, R. Diab, R. Diab, and A. Pasc, "Encapsulation of probiotics: insights into academic and industrial approaches," AIMS Materials Science, vol. 3, no. 1, pp. 114-136, 2016.

[17] R. L. Corona-Hernandez, E. Alvarez-Parrilla, J. Lizard Mendoza, A. R. IslasRubai, A. Delarosa, and A. WallMedrano, "Structural stability and viability of microencapsulated probiotic bacteria: a review," Comprehensive
Reviews in Food Science and Food Safety, vol. 12, no. 6, pp. 614-628, 2003.

[18] A. Bevilacqua, B. Speranza, A. Santillo et al., "Alginate-microencapsulation of Lactobacillus casei and Bifidobacterium bifidum: performances of encapsulated microorganisms and bead-validation in lamb rennet," Lebensmittel-Wissenschaft \& Technologie, vol. 113, p. 108349, 2019.

[19] M. Cay, İ. Kılıc, İ. Karagoz et al., "Molecular characterization of yoghurt bacteria isolated from beans and lentils," The Eurasia Proceedings of Science Technology Engineering and Mathematics, vol. 2, pp. 254-258, 2018.

[20] M. M. Valerie and H. L. Rawson, "Effects of exopolysaccharide-producing Sains of thermophilic lactic acid bacteria on the texture of stirred yoghurt," International Journal of Food Science and Technology, vol. 34, 1999.

[21] M. Dubois, K. A. Gilles, J. K. Hamilton, P. A. Rebers, and F. Smith, "Colorimetric method for determination of sugars and related substances," Analytical Chemistry, vol. 28, no. 3, pp. 350-356, 1956.

[22] M. E. Hull, "Determination of tyrosine concentration," Journal of Diary Science, vol. 30, pp. 881-884, 1974.

[23] F. Durlu-Ozkaya, V. Xanthopoulos, N. Tunail, and E. Litopoulou-Tzanetaki, "Technologically important properties of lactic acid bacteria isolates from Beyaz cheese made from raw ewes' milk," Journal of Applied Microbiology, vol. 91, no. 5, pp. 861-870, 2001.

[24] Aoac, Official Method of Analysis, Association of official analytical chemists, Gaithesburg, MD, USA, 2000.

[25] C. Wacher-Rodarte, M. V. Galvan, A. Farres, F. Gallardo, V. M. E. Marshall, and M. Garcia-Garibay, "Yogurt production from reconstituted skim milk powders using different polymer and non-polymer forming starter cultures," Journal of Dairy Research, vol. 60, no. 2, pp. 247-254, 1993.

[26] Idf, "General standard of identity for fermented milks," International Standard 163, International Dairy Federation, Brussels, Belgium, 1992.

[27] Turkish Standard, TS 1330/April 2006. Yoghurt, Turkish Standard Institution, Ankara, Turkey, 2006.

[28] E. Turhan, Z. Erginkaya, A. Bozdoğan, and Z. Aslan, "Farklı kaplama materyalleri ile kaplanmış lactobacillus rhamnosus'un thermal i?naktivasyon kinetiği," Journal of Food and Feed Science Science Technology, vol. 17, pp. 12-20, 2017.

[29] I. M. Fareez, S. M. Lim, R. K. Mishra, and K. Ramasamy, "Chitosan coated alginate-xanthan gum bead enhanced $\mathrm{pH}$ and thermotolerance of Lactobacillus plantarum LAB12," International Journal of Biological Macromolecules, vol. 72, pp. 1419-1428, 2015.

[30] T.-Y. Sheu, R. T. Marshall, and H. Heymann, "Improving survival of culture bacteria in frozen desserts by microentrapment," Journal of Dairy Science, vol. 76, no. 7, pp. 1902-1907, 1993.

[31] P. Ruas-Madiedo, R. Tuinier, M. Kanning, and P. Zoon, "Role of exopolysaccharides produced by Lactococcus lactis subsp. cremoris on the viscosity of fermented milks," International Dairy Journal, vol. 12, no. 8, pp. 689-695, 2002.

[32] X. Han, Z. Yang, X. Jing et al., "Improvement of the texture of yogurt by use of exopolysaccharide producing lactic acid bacteria," BioMed Research International, vol. 2016, Article ID 7945675, 6 pages, 2016

[33] A. E. Kılınç and Y. Gezginç, "Determination of the Potential Use of Exopolysaccharide-Producing Streptococcus salivarus ssp. thermophilus and Lactobacillus delbrueckii ssp. bulgaricus in Yoghurt," KSU Journal Of Agriculture and Nature, vol. 22, no. 2, pp. 401-408, 2019. 
[34] S. N. Rajagopal and W. E. Sandine, "Associative growth and proteolysis of Septococcus thermophlus and Lactobacillus bulgaricus in skim milk," Journal of Dairy, vol. 73, 1990.

[35] M. Karakus, "Beyaz peynirden i?zole edilen laktik asit bakterilerinin asit oluşturma ve proteolitik aktiviteleri," GIDA, vol. 16, no. 4, pp. 237-241, 1994.

[36] W. Liu, j. Yu, Z. Sun et al., "Relationships between functional genes in Lactobacillus delbrueckii ssp. bulgaricus isolates and phenotypic characteristics associated with fermentation time and flavor production in yogurt elucidated using multilocus sequence typing," Journal of Dairy Science, vol. 99, no. 1, pp. 89-103, 2016.

[37] N. Altay Dede, Characterization of lactobacillus delbrueckii subspecies bulgaricus and septococcus thermophilus as lactic cultures isolated from traditional turkish yoghurts and subtyping of septococcus thermophilus using crispr analysis and mlst, PhD Thesis, Middle East Technical University, Ankara, Turkey, 2010.

[38] K. B. Rechinger and H. Siegumfeldt, "Rapid assessment of cell viability of Lactobacillus delbrueckii subsp. bulgaricus by measurement of intracellular $\mathrm{pH}$ in individual cells using fluorescence ratio imaging microscopy," International Journal of Food Microbiology, vol. 75, no. 1-2, pp. 53-60, 2002.

[39] A. Korkmaz, "Some properties of stirred type yoghurts made from milk with adjusted fat content and added with exopolysaccharides-producing starter cultures," Master Thesis, Harran University, Turkey, 2005.

[40] E. Amani, M. H. Eskandari, and S. Shekarforoush, "The effect of proteolytic activity of starter cultures on technologically important properties of yogurt," Food Sciences and Nutrition, vol. 5, no. 3, pp. 525-537, 2017.

[41] V. Xanthopoulos, C. G. Ipsilandis, and N. Tzanetakis, "Use of a selected multi-strain potential probiotic culture for the manufacture of set-type yogurt from caprine milk," Small Ruminant Research, vol. 106, no. 2-3, pp. 145-153, 2012.

[42] M. Atamer and E. Sezgin, "Yoğurtlarda kuru madde artırımının pıhtının fiziksel özellikleri üzerine etkisi," Gıda Dergisi, vol. 11, no. 6, p. 327, 1986.

[43] İ. Uzunsoy, Geleneksel yoğurt örneklerinden izole edilen Lactobacillus delbrueckii subsp. Bulgaricus Ve Streptococcus Thermophilus Suşlarının Endüstriyel Yoğurt Üretimine Uygunlugunun Saptanarak Starter Kombinasyonlarmın Gelistirilmesi, PhD Thesis, Ankara University, Ankara, Turkey, 2018.

[44] K. Adhikari, I. U. Grün, A. Mustapha, and L. N. Fernando, "Changes in the profile of organic acids in plain set and stirred yogurts during manufacture and refrigerated storage," Journal of Food Quality, vol. 25, no. 5, pp. 435-451, 2002.

[45] O. B. Karaca, İ. B. Saydam, and M. Güven, "Physical, chemical, and sensory attributes of low-fat, full-fat, and fatfree probiotic set yogurts fortified with fiber-rich persimmon and apple powders," Journal of Food Processing and Preservation, vol. 43, no. 6, p. e13926, 2019.

[46] L. Yılmaz, Yoğurt Ve Benzeri Fermente Ürünleri Üretiminde Farklı Probiyotik Kültür Kombinasyonlarının Kullanımı, Uludağ Üniversitesi, Bursa, Turkey, 2006.

[47] S. Arslan and S. Bayrakçi, "Physicochemical, functional, and sensory properties of yogurts containing persimmon," Turkish Journal of Agriculture and Forestry, vol. 40, pp. 68-74, 2016.

[48] E.-S. El-Sayed and I. A. El-Gawad, "Utilization of laboratoryproduced xanthan gum in the manufacture of yogurt and soy yogurt," European Food Research and Technology, vol. 215, no. 4, pp. 298-304, 2002.
[49] E. D. Pancar, S. Andiç, and G. Boran, "Comparative effects of fish and cow gelatins and locust bean gum on chemical, textural, and sensory properties of yogurt," Journal of Aquatic Food Product Technology, vol. 25, no. 6, pp. 843-853, 2016.

[50] Z. Tarakçı and E. Küçüköner, "Physical, chemical, microbiological and sensory characteristics of some fruit-flavored yoghurt," Veterinerlik Fakültesi Dergisi, vol. 14, no. 2, pp. 10-14, 2003.

[51] C. Koçak and S. Aydemir, Süt Proteinlerinin Fonksiyonel Özellikleri. Gıda Teknolojisi Derneği Yay. No: 20, Ankara, Turkey, 1994.

[52] K. Koçak, Tüketime sunulan yoğurtlarda bazı katkı maddelerinin (nişasta, jelatin, natamisin) kullanımı ve mikrobiyolojik kalitesinin belirlenmesine yönelik piyasa araştırması. Yüksek Lisans Tezi, Afyon Kocatepe Üniversitesi, Fen Bilimleri Enstitüsü, Afyon, Turkey, 2013.

[53] W. Hozapfel, Advances in Fermented Foods and Beverages: Improving Quality, Techologies and Health Benefits. Edt. Wilhelm Hozapfel, Woodhead Publishing, Sawston, UK, 2015.

[54] Ş. Çelik, G. Şenocak, H. Durmaz, and G. G. Şat, "Andız pekmezi içeren set tipi yoğurtların bazı fizikokimyasal ve mikrobiyolojik özellikleri," Gıda, vol. 34, no. 4, pp. 213-218, 2009.

[55] M. R. Carbo, A. Bevilacqua, and M. Sinigaglia, "Shelf life of alginate beads containing lactobacilli and bifidobacteria: characterisation of microspheres containing Lactobacillus delbrueckiisubsp. Bulgaricus," International Journal of Food Science, Technology \& Nutrition, vol. 46, pp. 2212-2217, 2011.

[56] K. M. Amine, C. P. Champagne, S. Salmieri et al., "Effect of palmitoylated alginate microencapsulation on viability of Bifidobacterium longum during freeze-drying," LebensmittelWissenschaft und-Technologie-Food Science and Technology, vol. 56, no. 1, pp. 111-117, 2014.

[57] G. Frakolaki, V. Giannou, C. Tzia, G. Frakolaki, V. Giannou, and D. Kekos, "A review of the microencapsulation techniques for the incorporation of probiotic bacteria in functional foods," Critical Reviews in Food Science and Nutrition, vol. 1-22, 2020.

[58] R. Rajam and C. Anandharamakrishnan, "Microencapsulation of Lactobacillus plantarum (MTCC 5422) with fructooligosaccharide as wall material by spray drying," Lebensmittel-Wissenschaft und-Technologie-Food Science and Technology, vol. 60, no. 2, pp. 773-780, 2015.

[59] M. J. Martín, F. Lara-Villoslada, M. A. Ruiz, and M. E. Morales, "Microencapsulation of bacteria: a review of different technologies and their impact on the probiotic effects," Innovative Food Science \& Emerging Technologies, vol. 27, pp. 15-25, 2015.

[60] K. Kailasapathy, "Survival of free and encapsulated probiotic bacteria and their effect on the sensory properties of yoghurt," Lebensmittel-Wissenschaft \& Technologie, vol. 39, pp. 1224-1227, 2006.

[61] K. Sultana, G. Godward, N. Reynolds, R. Arumugaswamy, P. Peiris, and K. Kailasapathy, "Encapsulation of probiotic bacteria with alginate-starch and evaluation of survival in simulated gastrointestinal conditions and in yoghurt," International Journal of Food Microbiology, vol. 62, no. 1-2, pp. 47-55, 2000.

[62] K. Adhikari, A. Mustapha, I. U. Grün, and L. Fernando, "Viability of microencapsulated bifidobacteria in set yogurt during refrigerated storage," Journal of Dairy Science, vol. 83, no. 9, pp. 1946-1951, 2000. 